\title{
Evaluating the Optional Tours Service Quality and its Effect on Tourist's Satisfaction in Marsa Alam City
}

\author{
Mohammed A. Khalaf ${ }^{\text {a }}$ \\ Ghada Mohamed Wafik ${ }^{\mathrm{c}}$, \\ , Wafaa Ahmed Elias ${ }^{\mathrm{b}}$, \\ a Assistant Lecturer , Tourism studies Department, Faculty of Tourism and \\ Hotels , Minia University \\ ${ }^{\mathrm{b}}$ Professor, Tourism studies Department, Faculty of Tourism and Hotels, \\ Minia University \\ c Professor, Tourism studies Department, Faculty of Tourism and Hotels, \\ Fayom University
}

\section{Keywords}

Optional Tours

Services Quality

Tourist Satisfaction

Marsa Alam

\begin{abstract}
Optional Tours are one of the most important activities in the tourism industry and can provide substantial gains to tourists and tourism businesses as well as host communities. In addition, optional tours are now one of the main products in Egypt. The purpose of this paper is to evaluate the of optional tours services presented by travel agencies and their effect on tourist's satisfaction in Marsa Alam city. To achieve the aims of the study, quantitative approach based on a questionnaire was developed and directed to a sample of Egyptian and foreign tourists. The questionnaire was handled to 550 Egyptians tourists and 140 foreign tourists. Out of this number, 452 forms were available for analysis representing $82.1 \%$ response rate for Egyptian tourists and 97 forms were available for analysis representing $69.3 \%$ response rate for foreign tourists. The results indicated that Egyptians tourists felt safe during implementing their optional tours, whereas, the foreign tourists are satisfied with modern technology which travel agencies used in showing and selling optional tours. Moreover, the Egyptians tourists suffered from not providing the need information about the trip, whereas, foreign tourists suffered from the travel agency not implemented the optional tours as had been announced and purchased.
\end{abstract}

Online ISSN 2735-4741 


\section{Introduction}

Deregulation and globalization have increased competitive pressures, helping to bring down prices and to improve the quality of services provided by professional tourism destinations. The 1980s witnessed many service industries placing increased emphasis on managing quality. Traditional ideas of quality, which had evolved from manufacturing industries and had been based on the conformance to the standards defined by operation management, began to be replaced by customer-focused notions. This required close consideration of what the customer wanted and how their needs could be met. Different dimensions of service were defined and customer satisfaction, considered to be the gap between perceived and expected service, was assessed (Eraqi, 2006).

The area of tourism has been significantly expanding in recent years, which is beneficial for the economic and political as well as the social spheres of many countries. Tourism becomes an inseparable part of social and modern lives for many people. To be able to sustain competitiveness it is inevitable to pay remarkable attention to the quality offered. With regard to the specific character of services, especially their tangibility, evanescence and variability, it is rather difficult to measure this quality and so in practice we can meet different approaches and understandings the quality of services (Prabaharan et al., 2008).

Travel agencies were considered major actors in tourism industry development. They were considered as an intermediate channel between customers and service providers. They also promoted the products presented by holiday suppliers like hotels, sightseeing operators, excursions, etc. (Chang, 2008). They played an important role in offering optional excursion as it has an incredible energy which impact and direct tourist demand. They were not just mediators but also they act as an interface amongst supply and diverse segments of demand. Travel agencies should pay attention to the Tourist satisfaction. Tourist satisfaction should be understood by travel agencies and should serve as a basis for assessing the performance of products and service destination. Chang (2008) mentioned in his study that satisfied customer repeat his/her experience to buy the products and also create new customers by communication of positive message about it to others. On the other hand, dissatisfied customer might switch to alternative products/services and communicate negative message to others. 
Tourist satisfaction was the key factor of successfulness in tourist industry and a key to long-term business success. To protect or gain market shares, organizations need to outperform competitors by offering high quality product or service to ensure satisfaction of customers. This was extremely important to clarify which dimensions affect the satisfaction in tourist industry. Also, consequences of tourists' satisfaction and dissatisfaction should be studied to provide adequate knowledge for decision makers in this sector (Sadeh et al, 2012).

Al-Ababneh (2013) confirmed that tourism service quality directly impacted tourist satisfaction throughout destination accessibility, destination facilities, and destination attraction. Destination accessibility includes the cost, speed and convenience of the public transport around the tourist destination. Accommodations, restaurants, Café and transportation service can be categorized in destination facilities, which also includes other facilities in the tourist destination like retail shop and souvenirs shop and other service like information service and tourist police. Attraction and environment of destination could motivate tourists to visit the place, especially places with modern and historic architecture, heritage, culture, art, and etc.

Customer satisfaction was a primary objective for any business (Ashraf et al, 2018), and several studies have been conducted on the subject due its significant effects on organizations such as profitability, increased purchase intentions (Ghotbabadi et al, 2016), gaining a competitive advantage (Asadpoor and Abolfazli, 2017), creating or reinforcing long-term relationships with customers (Tabaku and Cerri, 2016), and loyalty. Satisfied customers were in general more likely to become repeat customers and recommend the company to new potential ones (Sukri et al, 2014).

The research aims to evaluate the level of optional tours services which provided to tourists during their tour, and its effect on tourists' satisfaction in Marsa Alam city. The research contains introduction, literature review, methodology, findings and discussion and conclusion.

\section{Literature review}

\subsection{Concept of Optional Tours}

Optional tours were characterized by travelling to closer tourist destinations in a relatively short period of time, considering that normally they did not last longer than 24 hours. This meant that unlike other forms and types of tourist traffic they often did not 
include overnight services. Although in terms of duration they might take half a day, full day, or a few hours, optional tours might be purely recreational or purely cultural, but in their form and essence they were a combined type of tourist movements. They were distinguished from other forms of tourist types and movements primarily by their duration, and not less by their radius. Specifically, these were short-term movements in the immediate and extended environment of tourist dispersion (Stetic et al, 2011).

$\mathrm{Yu}(2012$, p.93) defined Optional attractions and activities as "those are not included in the tour price participation in these will cost the traveler extra money". Travel agencies not only considered as the main source of travel information for most travelers but also a provider of a variety of services that are quite important for travelers (Hui and Wan, 2005). Richey et al. (2010) mentioned that travel agencies improve their product development in the market by collaborating with partners to satisfy consumers' needs. Huang (2008) stated that travel agencies have to innovate and develop new products to gain competitive advantage and services to reach consumers' satisfaction. Innovation is at the heart of any successful company's agenda. Optional Tours consider a form of innovative products which their effects are reflected on customers, companies and host community. Tour guide and tour leader play an important role not only in the selection of attractions, Optional Tours or shopping (Wang et al., 2002) but also in the achievement of customer satisfaction (Chan et al., 2015).

Optional Tours were one of the most important activities in the tourism industry and might provide substantial gain to tourists and tourism businesses as well as host communities. Optional Tours were considered as a type of tourism experience such as adventure tourism, thus it is defined as "a type of tourism experience where a tour operator offers travelers an opportunity to participate tourism activities, as well as a cultural exchange with local people" (Brown, 2005, p. 480).

\subsection{Marketing and Selling Optional Tours}

Marketing in tourism requires a good knowledge of the exigencies and trends of the market, the orientation of the supply of tourism products according to the size and structure of the demand, the establishment of a price and pricing strategy, a distribution platform, the use of effective tools for promoting the tourism product, estimating sales opportunities by seasonality (Sofronov, 2019). 
Optional tours often play a role as distinguishing features in attracting tourists who prefer more flexibility in choosing tour products. In addition, the marginal profit of optional tours was often greater than that of predesigned tours. As a result, tour operators were motivated to increase their offerings of optional tours (Guo et al., 2014).

Travel agencies were more tourist-oriented nowadays than ever before. They had to keep up according to the change of tourists' needs in order to reach their satisfaction. According to Huhtiniemi (2008) retaining existing tourists was easier than acquiring new ones, so the efforts made to please their customers are worthwhile. Optional Tour was any attraction which set out to attract local and international tourists. It was developed to be more and more attractive and achieve visitors' satisfaction.

\subsection{Tourism Services Quality}

Tourism quality was considered a classificatory term used by tourists to describe their re-construction of a tourist journey. As Jennings and Weiler (2006, p57) claimed, "this term may mean excellence, a matching of expectations to lived experience, a perception of getting value for one's money, or however the individual tourist chooses to define it".

Tourism is a highly competitive industry, and tourism enterprise sector can no longer compete on the basis of cost alone. Quality is, therefore, a key element for the competitiveness of the tourism industry. It is also important for the sustainable tourism development of the industry and for creating and improving jobs. Therefore, promoting quality in tourism and tourist products is a priority in different tourism activities (Eraqi, 2006).

Service quality is considered as a standard used to assess the effectiveness of a particular leisure service agency, including the tourism service sector. Therefore, the quality of service involved with tourism plays an important role in the process of delivery. Further, the quality of service influenced customers' image that had an effect on the process from expected quality to perceived quality (Prabaharan et al., 2008). Tourism is arguably one of the largest self-initiated commercial interventions to create happiness on the entire planet. Happiness is directly related to satisfaction, and therefore overall happiness is highly linked to satisfaction in leisure travel sector. The majority of tourists have experiences with destinations, and their perceptions are influenced by comparisons among facilities, attractions, and service standards (Glatzer, 2000). 
In tourism literature, quality had been associated with different meanings in a variety of contexts, in particular service delivery and quality; quality assurance, auditing and control; and in product and market differentiation (Warden et al, 2003; Lennon and Harris, 2002). However, Jennings and Weiler (2006) advanced that 'service quality' covered a greater range of perspectives than just service quality. The term tended to be associated with product quality importance (Onome, 2003), the relationship between quality and satisfaction (Singh and Tomar, 2013) as well as quality and environmental issues across a range of environments from natural to build (Lawson et al, 2003). Furthermore, tourism services quality had been linked to sustainability (Paul and Sreejesh, 2017); host and guest interactions (Su and Wall, 2010); quality of life (Meng et al, 2010) and motivation (MacCannell, 2002). The majority of the studies conducted into quality of tourism services tended to understand the relation between quality and satisfaction.

\subsection{Tourist Satisfaction Concept}

$\mathrm{Hu}$ et al. (2009) declared that customer satisfaction as a judgment made on the basis of a specific service encounter. It is a main focus of research in many tourism studies due to its importance in determining the success and the continued existence of the tourism business (Gursoy et al., 2007) and the benefits it brings to organizations (Ranaweera and Prabhu, 2003; Ali and Zhou, 2013; Amin and Nasharuddin, 2013; Weng and de Run, 2013). Angelova and Zekiri (2011) clarified that customer satisfaction was strongly linked to the experience and expectations of customers, and real customer satisfaction represents the difference between what customers actually expect to get and the actual service performance exceeding such expectations.

In recent times, organizations of all types and sizes have increasingly come to understand the importance of customer satisfaction. It is widely understood that it is far less costly to keep existing customers than it is to win new ones, and it is becoming accepted that there is a strong link between customer satisfaction, customer retention and profitability (Oliver, 1981). O'Sullivan and McCallig (2012) showed that customer satisfaction has a positive impact on firm value. Critically, the authors found that this impact is over and above the impact that earnings have on firm value, and that 
customer satisfaction positively and significantly moderates the earnings-firm value relationship (O'Sullivan and McCallig, 2012).

According to Westbrook and Oliver (1991) customer satisfaction was defined as positive post-consumption feelings. Instead of exploring cognitive outcomes, customer satisfaction was considered to be an effective measure of usefulness of a product or service availed by customers (Berezina et al., 2012). Moreover, various scholars (e.g. Cronin and Taylor, 1992; Seth et al., 2005) have agreed that re-purchase intention is strongly associated with customer satisfaction. Likewise, customer satisfaction serves as a major element for customer retention (Abdullah et al., 2011; Farooq et al., 2016).

Moreover, Kotler and Caslione (2009) added that satisfaction referred "to a person's feeling of pleasure or disappointment resulting from comparing a product's performance in relation to his or her expectations". Customer satisfaction have remained a key focus area in many social and behavioral studies (e.g. Chen et al., 2012). The concept of customer satisfaction was generally based on the notion that a business must satisfy its customers in order to be sustainable and profitable (Izogo and Ogba, 2015; Radovic-Markovic et al., 2017).

Tourist satisfaction can be analyzed as a relationship between the sacrifices and rewards he expects in terms of time, cost or effort and value received. Tourists compared their present destination with other alternative or past experience (Yoon and Usal, 2005). Tourist satisfaction with a particular destination might be the result of multiple factors, including the expectations generated before and during the trip, as well as the tourist's perception of service received. Tourist satisfaction reflects both a cognitive and an emotional phenomenon (Bigné and Andreu 2004). The analysis of the causes of that generate satisfaction was much scarcer. Among the different types of antecedents that influence tourist satisfaction, a great deal of analysis has been directed towards the attributes of the service offering.

Namukasa (2013) agreed with the definition of satisfaction as the feeling of pleasure or disappointment when a customer compares a product's perceived performance with his or her prior expectations (Oliver, 1981; Tse and Wilton, 1988). Clearly customer satisfaction was a post-decision experience. Service quality and customer satisfaction were closely related but not interchangeable, although both concepts involved a comparison of expectations of quality and the actual service received. 


\subsection{Tourism Services Quality and Tourist Satisfaction}

With the rapid advancements in competitive business environment, customer expectations and demands were also increasing, leading to a situation where many companies - especially travel agencies- find it difficult to retain their customers (Ali et al, 2015). Moreover, failure to recognize true needs and wants of customers was also a barrier to provide high quality services (Izogo and Ogba, 2015). Today's competitive market situation has forced travel agencies to focus on cost reduction for achieving efficient business operations; however, while doing so the element of service quality and customer satisfaction is often compromised (Boetsch et al, 2011).

Satisfaction was the evaluation of the performance of the overall services provided by the firm received by the customer. Satisfaction was an important factor to be taken into account by the customer in deciding whether to continue a purchase or otherwise. Satisfaction results when performance exceeded the requirements. On the other hand, when the requirements exceeded the performance, dissatisfaction will result (Bitner, 1990; Roy et al, 2016).

To achieve a high level of customer satisfaction, most researchers suggested that a high level of service quality should be delivered by the service provider as service quality was normally considered an antecedent of customer satisfaction. However, the exact relationship between satisfaction and service quality has been described as a complex issue, characterized by debate regarding the distinction between the two constructs and the casual direction of their relationship (Cronin et al, 2000).

Considerable confusion continued to exist regarding the relationship between customer satisfaction and service quality (Burns et al., 2003). Caruana (2000) claimed that service quality and satisfaction have often been used interchangeably. Distinctions between customer satisfaction and service quality include: a) satisfaction was a post experience decision customer experience while quality is not; b) in the satisfaction literature "expectations reflect anticipated performance" made by customers about levels of performance during a transaction. In the service quality literature, expectations were conceptualized as a normative stand of future wants.

Customer's feelings and beliefs also affected their satisfaction level. If the customers of an organization are satisfied by their services the result is that, they will be loyal to them and consequently be retained by the organization, which is positive for the organization 
because it could also mean higher profits, higher market share, and increasing customer base (Karatepe et al., 2005). Customer satisfaction has become important due to increased competition as it was considered very important factor in the determination of travel agencies' competitiveness. Continuous measurement of satisfaction level was necessary in a systematic manner (Chakravarty et al., 1996). Because satisfied customer was the real asset for an organization that ensures long-term profitability even in the era of great competition.

Quality and satisfaction clearly impact the evaluation of tour by a consumer and any discussion without them would be incomplete. Service quality was notoriously difficult and elusive to define particularly when referring to tourism services (Jennings et al., 2009). A well-accepted view of quality was that it was a comparison between expectations and performance (Bowen and Clarke, 2002). Satisfaction remains an 'elusive, indistinct and ambiguous construct' (Yuksel and Yuksel, 2002: 53) and was often used incorrectly as a synonym for the term 'quality' by tourism researchers (Bowen, 2001).

Academics often used the terms quality and satisfaction interchangeably. However, Bowen and Clarke (2002) regard satisfaction to be more emotional than quality. They argue that judgments of service quality compared more to service expectations of industry standards and managerial specifications, whereas service satisfaction involved making comparisons of the consumer against their own specifications and benchmarks.

\subsection{Marsa Alam City}

Marsa Alam is a city located on the western shore of the Red Sea; it is located $274 \mathrm{~km}$ south of Hurghada city. The pleasant climate makes it a great vacation spot, winter temperatures have been known to reach $31 \mathrm{C}$ and in summer they lie between 20 and 35C. For less experienced divers, in-shore coral reefs are the ideal location for hours of marine wildlife watching. Marsa Alam has become a fast growing tourist city due to its fantastic beaches, tranquility and wonderful climate and nature. Marsa Alam has several attractions as International Airport. The nearby National Parks of Gebel Elba and Wadi al Gimal are home to a stunning variety of birds and desert animals. Marsa Alam is also known as a therapeutic destination. Marsa Alam contains a verity of optional tours like safari tours which contains camping, badawia concert, beach buggy, horse and camel rides. Another form of optional tours is those marine activities which 
contain diving, snorkeling, swimming and fishing (Red Sea Governorate, 2020; Egyptian Tourism Authority, 2020).

\section{Methodology}

The purpose of the field work is to evaluate the level of tourism optional tours quality and its influence one tourist's satisfactions. Furthermore, the study investigated the relationship between the quality of the optional tours services and the overall satisfaction in the investigated city. To achieve the aim of the research, quantitative approach based on a questionnaire was developed and directed to a sample of tourists visited Marsa Alam city during 2020. Marsa Alam city was chosen for the field work application as it was important tourist destination in Egypt according to (Red Sea Governorate, 2020).

\subsection{Designing the questionnaire}

To achieve the aim of research a questionnaire form was designed and handled to a sample of tourists during 2020. The questionnaire was three pages long and it wouldn't take more than 10 minutes to fill-in by respondents. A combination of close-ended and open-ended questions is used. The tested issues were created by the researcher and selected according to the review of the literature.

The questionnaire contained 8 questions, dividing into three parts. The first part is for the demographic questions and the trip arrangements i.e. age, gender, income categories, education level and trip arrangements. This part consists of five statements. The second part is concerned with evaluating the optional tours services. This part consisted of one statement. The third part consisted of one statement asking the tourists about their overall satisfaction about the quality of optional tours services provided during their tour.

\subsection{The research sample and collecting data}

The questionnaire was directed to Egyptian and foreign tourists. The questionnaire was directed to Egyptian tourists distributed with two ways, hard forms handled to 250 Egyptian tourists. Out of this number 216 forms are valid to be analyzed (representing $86.4 \%$ response rate). These questionnaire forms were distributed from September 2020 to November 2020. The research distributed these forms by himself and his assistants during the last two days before the tourist's departure. 
The second way is online questionnaire on google drive available at (https://docs.google.com/forms/d/19TGuvqvzR95u0MPDryRMaaj_8 Yju1e3ZB6wHuNC0Uw8/edit?usp=sharing) this questionnaire had been answered by 300 participate. Out of this number 236 forms are valid to be analyzed (representing $78.7 \%$ response rate). These questionnaire forms were available online from September 2020 to November 2020. The questionnaire was analyzed by SPSS version 18 by calculating frequencies, percentage, means and standard deviation. Correlations between level of Egyptian tourist's satisfaction and some other items of the study are also tested.

Another questionnaire form was directed to foreign tourists. The questionnaire was handled to 140 tourists. Out of this number 97 forms are valid to be analyzed (representing 69.3\% response rate). These questionnaire forms were distributed from September 2020 to November 2020.

\section{Findings and Discussion}

\subsection{The Questionnaire Directed to Egyptian Tourists}

The findings and discussion results of questionnaire directed to Egyptian tourists was divided into five parts; every part was analyzed individually.

\subsubsection{The First Part: Data Validity and Reliability}

\subsubsection{Data Validity}

To validate the data collection instrument utilized in this study in terms of its readability, format, and ability to measure the study's constructs; the researcher distributed the questionnaire instrument to a number of tourists in the investigated city. The questionnaire instrument was then updated and refined to reflect the comments and suggestions received by sample of tourists. Moreover, the tourists showed interest and interacted with the researcher concerning the questionnaire instrument which adds to its validity.

\subsubsection{Data Reliability}

The reliability of an instrument was the degree of accuracy and consistency with that it measures whatever it is measuring (Ary et al., 2002). Before proceeding with further analysis, the reliability testing was leaded in order to ensure consistent measurement across various items in the questionnaire. Indeed, the reliability of a measure indicates stability and consistency of the instrument. Consequently, this method determined reliability through examining the internal 
consistency of the research instrument such as questions (items) in the questionnaire, which were normally presented. Cronbach's alpha coefficient measures this effect and ranges from 0 (no internal consistency) to 1 (maximum internal consistency). Reliability coefficient of 0.70 or higher is considered "acceptable" in most social science research situations (Döckel, 2003).

As depicted in table (1), the Cronbach's Alpha Reliability was computed for two items. The tests showed that the Reliability Coefficients for all the sections were equal 0.898 and Validity Coefficient for all the sections were equal 0.947 which indicates that the instrument is reliable for being used.

Table (1) Cronbach's Alpha Value of Tourist's Sample

\begin{tabular}{|c|c|c|c|}
\hline Variables & $\begin{array}{c}\text { No. of } \\
\text { items }\end{array}$ & $\begin{array}{c}\text { Cronbach's } \\
\text { Alpha } \\
\text { Value }\end{array}$ & $\begin{array}{c}\text { Validity } \\
\text { Coefficient } *\end{array}$ \\
\hline Optional Tours & 7 & .889 & .942 \\
\hline $\begin{array}{c}\text { Tourist } \\
\text { satisfaction }\end{array}$ & 1 & .847 & .920 \\
\hline Total & 8 & .898 & .947 \\
\hline
\end{tabular}

$*$ Validity coefficient $=\sqrt{ }$ Reliability coefficient

In order to measure the internal consistency and reliability of the study's constructs. Cronbach's Alpha $(\alpha)$ measure was used. The scales' reliabilities were measured and the Cronbach's Alpha of all scales in Table (1) ranged from 0.889 to 0.847 , and for total questionnaire items was (0.898), this indicate an acceptable Cronbach's Alpha value for each field, whenever Cronbach's Alpha value is acceptable if it's more than (0.7). It is also evident that the validity coefficient is (94.7\%) which means the reliability and validity of the study sample are accepted.

\subsubsection{The Second Part: Personal Data and Travel Arrangements}

Table (2) illustrated the different variables of the study through five sections about the Gender, Age Group, Average Income, Educational Level and the trip arrangements. 
Table 2: Personal Date and Travel Arrangements of the Egyptian Sample

\begin{tabular}{|c|c|c|}
\hline Variable & Frequency & Percentage (\%) \\
\hline \multicolumn{3}{|c|}{ Gender } \\
\hline Male & 358 & 79.2 \\
\hline Female & 94 & 20.8 \\
\hline \multicolumn{3}{|c|}{ Age Group } \\
\hline Less than 25 & 196 & 43.4 \\
\hline Between 25 and 50 & 230 & 50.9 \\
\hline Over than 50 & 26 & 5.7 \\
\hline \multicolumn{3}{|c|}{ Average Income } \\
\hline Less than 4000 & 214 & 47.3 \\
\hline From 4001 to 6000 & 186 & 41.2 \\
\hline From 6001 to 8000 & 46 & 10.2 \\
\hline Over 8000 & 6 & 1.3 \\
\hline \multicolumn{3}{|c|}{ Education level } \\
\hline Average Education & 126 & 27.9 \\
\hline Higher Education & 266 & 58.8 \\
\hline Master/ PhD & 60 & 13.3 \\
\hline Are your trip organized by a travel agency? \\
\hline Yes & 452 & 82.1 \\
\hline No & 550 & 17.9 \\
\hline
\end{tabular}

Table (2), declared that eighty percent are males, whilst only twenty are females. Middle age category from 25 to 50 category represents the highest percentage of Egyptian tourists (51\%), The second level of the respondents which reaches (44\%) from the total sample size. The majority of the sample $47 \%$ their income is less than 4000 , whereas $(41 \%)$ of respondents their income is from 4001-6000, while less percentage of the sample their average income over than 8000. A large percentage (59\%) of the total sample is higher education, whilst (28\%) of respondents is average education, the rest percentage $(13 \%)$ is Master/ $\mathrm{PhD}$. The tourists sample asked if they organized their trip by a travel agency, the majority (82\%) of the Egyptian tourist's sample organized their trip by a travel agency, this rate is valid to analysis and the other rate is invalid to analysis . 


\subsubsection{The Third Part: Egyptians Tourist's Sample Assessment of Optional Tours Services}

Table (3): Respondents Assessment of Optional Tours Quality

\begin{tabular}{|c|c|c|c|c|c|c|c|}
\hline \multirow{2}{*}{ Statement } & \multicolumn{3}{|c|}{ Percentage } & \multirow{2}{*}{ Mean } & \multirow{2}{*}{$\begin{array}{c}\text { Std. } \\
\text { Deviation }\end{array}$} & \multirow{2}{*}{ Rank } & \multirow{2}{*}{ Attitude } \\
\hline & DA & $\mathbf{N}$ & $\mathbf{A}$ & & & & \\
\hline $\begin{array}{l}\text { The travel } \\
\text { agency uses } \\
\text { modern and } \\
\text { attractive ways } \\
\text { to show and } \\
\text { sell its optional } \\
\text { tours } \\
\text { (PowerPoint } \\
\text { presentations, } \\
\text { videos, } \\
\text { pictograms). }\end{array}$ & 2.2 & 17.7 & 80.1 & 2.78 & .466 & 3 & High \\
\hline $\begin{array}{c}\text { The travel } \\
\text { agency } \\
\text { provides } \\
\text { optional tours } \\
\text { that suitable } \\
\text { the nature of } \\
\text { the destination } \\
\text { and your } \\
\text { desires }\end{array}$ & .9 & 21.2 & 77.9 & 2.77 & .442 & 4 & High \\
\hline $\begin{array}{l}\text { The travel } \\
\text { agency } \\
\text { implements the } \\
\text { optional tours } \\
\text { as had been } \\
\text { announced and } \\
\text { purchased }\end{array}$ & 2.7 & 19.5 & 77.8 & 2.75 & .490 & 6 & High \\
\hline $\begin{array}{l}\text { The travel } \\
\text { agency } \\
\text { provides you } \\
\text { with the } \\
\text { information }\end{array}$ & 1.3 & 23 & 75.7 & 2.74 & .467 & 7 & High \\
\hline
\end{tabular}




\begin{tabular}{|c|c|c|c|c|c|c|c|}
\hline \multirow{2}{*}{ Statement } & \multicolumn{3}{|c|}{ Percentage } & \multirow[t]{2}{*}{ Mean } & \multirow{2}{*}{$\begin{array}{c}\text { Std. } \\
\text { Deviation }\end{array}$} & \multirow[t]{2}{*}{ Rank } & \multirow[t]{2}{*}{ Attitude } \\
\hline & DA & $\mathbf{N}$ & $\mathbf{A}$ & & & & \\
\hline $\begin{array}{l}\text { need about the } \\
\text { trip and the } \\
\text { staff responds } \\
\text { to all your } \\
\text { inquiries. }\end{array}$ & & & & & & & \\
\hline $\begin{array}{l}\text { You feel safe } \\
\text { during } \\
\text { implementing } \\
\text { the optional } \\
\text { tours. }\end{array}$ & .5 & 19 & 80.5 & 2.80 & .411 & 1 & High \\
\hline $\begin{array}{l}\text { The tour leader } \\
\text { does his fullest } \\
\text { role, caring of } \\
\text { your } \\
\text { satisfaction and } \\
\text { safety. }\end{array}$ & 2.7 & 15.9 & 81.4 & 2.79 & .470 & 2 & High \\
\hline $\begin{array}{l}\text { The transfers to } \\
\text { and from the } \\
\text { optional tour's } \\
\text { areas was } \\
\text { accurate and } \\
\text { smooth. }\end{array}$ & 1.8 & 21.2 & 77 & 2.75 & .471 & 5 & High \\
\hline
\end{tabular}

Respondents were asked to evaluate optional tours quality which arranged to them during their tours. Table (3) reflects the means and standard deviations of (Optional tours quality), where the means ranged between $(2.80-2.74)$ compared with the total instrument mean for the domain (2.77). The majority of the sample agreed with "They feel safe during implementing the optional tours" ranked first with a mean and standard deviation (Mean=2.80, standard deviation $=.411$ ) compared with the total instrument mean and the standard deviation. Whereas, $81 \%$ of the sample agreed with the tour leader does his fullest role, caring of your satisfaction and safety. Wong and Lee (2012) stated that the tour leader is an ambassador who presented the destination in a way that makes visitors want to return and is a host who could create a comfortable environment for the guest. Her/his presentation can make or break a 
tour also asserted that the performance of the tour leaders can affect a tourist satisfaction, company's image, customer loyalty (Wang et al., 2002). The item " The travel agency provides you with the information need about the trip and the staff responds to all your inquiries" ranked last reached a mean (2.74) and the standard deviation was (.467) compared with the mean and standard deviation of the total instrument.

\subsubsection{The Fourth Part: The Overall Satisfaction Level of Egyptians Tourists towards Their Trip in Marsa Alam}

Table 4: The Overall Satisfaction Level of the Egyptians Sample

\begin{tabular}{|c|c|c|c|c|c|}
\hline \multirow{2}{*}{ Service } & \multicolumn{3}{|c|}{ Percentage } & \multirow{2}{*}{ Mean } & \multirow{2}{*}{ Std. Deviation } \\
\cline { 2 - 4 } & $\mathbf{D S}$ & $\mathbf{N}$ & $\mathbf{S}$ & & .617 \\
\hline Optional Tours & 8.4 & 13.7 & 77.9 & 2.69 & \\
\hline
\end{tabular}

In this part, the tested Egyptians tourists were asked to evaluate their overall satisfaction level toward optional tours services provided to them during their trip (Table 4). A great proportion (78\%) declare that they are satisfied about the optional tours quality $(\mathrm{M}=2.69, \mathrm{SD}=.617)$. Whereas, only $8 \%$ of the sample respondents were dissatisfied about the optional tours quality provided to them. Customer satisfaction was a closely related construct to service quality and has received substantial attention from researchers and industry practitioners alike. Tourist tour was the ultimate product that the industry sold and promoted to customers. The outcome of the tourism experience was highly dependent on the quality of tour operations offered to tourists, and was represented and evaluated by "tangible" facilities/amenities and the "intangible" service encounters (Sirakaya et al., 2004). Therefore, customer satisfaction was a function of the perception of the totality of a consumption experience, which included the "what" and "how" aspects of services, and was influenced by factors such as social interactions, motivations, mood, preexisting and/or post attitudes, as well as special events (Baker and Crompton, 2000).

\subsubsection{The five Part Pearson Correlation between Egyptian Tourists Satisfaction and Optional Tours Services Provided to them during their Trip:}


Table (8) Correlation between Egyptian tourist's satisfaction and optional tours quality

\begin{tabular}{|c|c|c|}
\hline \multirow{2}{*}{ Satisfaction } & Pearson Correlation & Optional Tours \\
\cline { 2 - 3 } & Sig. (2-tailed) & $.914^{* *}$ \\
\cline { 2 - 3 } & $\mathrm{N}$ & .000 \\
\hline \multicolumn{2}{|c|}{$* *$. Correlation is significant at the 0.01 level (2-tailed). } \\
\hline
\end{tabular}

As seen in the table (8), there is a positive and significant relationship between security control and image perception. The value of spearman correlation coefficient was $\left(.914^{* *}-\operatorname{sig}=0.000\right)$. These results show that there is strong positive relation between Egyptian tourist's satisfaction and optional tours services quality. This positive correlation indicates that as Egyptians tourist's satisfaction increases with interest optional tours quality.

\subsection{The Questionnaire Directed to Foreign Tourists}

The findings and discussion results of questionnaire directed to foreign tourists was divided into five parts; every part was analyzed individually.

\subsubsection{The First Part: Data Validity and Reliability}

\subsubsection{Data Validity}

To validate the data collection instrument utilized in this study in terms of its readability, format, and ability to measure the study's constructs; the researcher distributed the questionnaire instrument to a number of foreign tourists. The questionnaire instrument was then updated and refined to reflect the comments and suggestions received by the foreign tourists. Moreover, the foreign tourists showed interest and interacted with the researcher concerning the questionnaire instrument which adds to its validity.

\subsubsection{Data Reliability}

As depicted in table (9), the Cronbach's Alpha Reliability was computed for two sections. The tests showed that the Reliability Coefficients for all the sections were equal 0.793 and Validity Coefficient for all the sections were equal 0.890 which indicates that the instrument is reliable for being used. 
Table (9) Cronbach's Alpha Value of Foreign Tourist's Sample

\begin{tabular}{|c|c|c|c|}
\hline Variables & $\begin{array}{c}\text { No. of } \\
\text { items }\end{array}$ & $\begin{array}{c}\text { Cronbach's } \\
\text { Alpha } \\
\text { Value }\end{array}$ & $\begin{array}{c}\text { Validity } \\
\text { Coefficient } *\end{array}$ \\
\hline Optional Tours & 7 & .760 & .871 \\
\hline $\begin{array}{c}\text { Tourist } \\
\text { satisfaction }\end{array}$ & 1 & .785 & .886 \\
\hline Total & 8 & .793 & .890 \\
\hline
\end{tabular}

$*$ Validity coefficient $=\sqrt{ }$ Reliability coefficient

In order to measure the internal consistency and reliability of the study's constructs. Cronbach's Alpha $(\alpha)$ measure was used. The scales' reliabilities were measured and the Cronbach's Alpha of all scales in Table (1) ranged from 0.785 to 0.760 , and for total questionnaire items was (0.793), this indicate an acceptable Cronbach's Alpha value for each field, whenever Cronbach's Alpha value is acceptable if it's more than (0.7). It is also evident that the validity coefficient is (89\%) which means the reliability and validity of the study sample.

\subsubsection{The Second Part: Personal Date and Travel Arrangements}

Table (10) indicated that the different variables of the study through five elements about the Gender, Age Group, Average Income, Educational Level and the trip arrangements.

Table 10: Personal and field work data of the foreign sample

\begin{tabular}{|l|c|c|}
\hline \multicolumn{1}{|c|}{ Variable } & Frequency & $(\%)$ \\
\hline Gender & 58 & 59.8 \\
\hline Male & 39 & 40.2 \\
\hline Female & \multicolumn{2}{|l|}{} \\
\hline Age Group & 41 & 42.3 \\
\hline Less than 25 & 47 & 48.5 \\
\hline Between 25 and 50 & 9 & 9.3 \\
\hline Over than 50 & \multicolumn{1}{|l|}{} \\
\hline Average Income & 53 & 54.6 \\
\hline Less than 2000 & 36 & 37.1 \\
\hline From 2001 to 4000 & 8 & 8.3 \\
\hline Over 4000
\end{tabular}




\begin{tabular}{|l|c|c|}
\hline \multicolumn{3}{|l|}{ Education level } \\
\hline Average Education & 49 & 50.5 \\
\hline Higher Education & 42 & 43.3 \\
\hline Master/ PhD & 6 & 6.2 \\
\hline \multicolumn{2}{|c|}{ Are your trip organized by a travel agency? } \\
\hline Yes & 97 & 69.2 \\
\hline No & 43 & 30.8 \\
\hline
\end{tabular}

Table (10), illustrated that sixty percentages are males, whilst only forty are females. Middle age category from 25 to 50 category represents the highest percentage of Egyptian tourists (48\%), The second level of the respondents which reaches (42\%) from the sample size. The majority of the sample 54\% their income less than 2000 , whereas $(37 \%)$ of respondents their income from 2001-4000, while less percentage of the sample their average income over than 4000 . A large percentage $(50 \%)$ of the total sample is average education, whilst $(43 \%)$ of respondents is higher education, the rest percentage (19\%) is Master/ PhD. The tourists sample asked to if the sample organized their trip by a travel agency, the majority (69\%) of the foreign tourist's sample organized their trip by a travel agency, this rate is valid to analysis and the other rate is invalid to analysis.

\subsubsection{The Third Part: Foreign Tourist's Sample Assessment of Optional Tours Services}

Table (11): Tourists Sample Assessment of Optional Tours Quality

\begin{tabular}{|c|c|c|c|c|c|c|c|}
\hline \multirow{2}{*}{ Statement } & \multicolumn{2}{|c|}{ Percentage } & Mean & $\begin{array}{c}\text { Std. } \\
\text { Deviation }\end{array}$ & Rank & Attitude \\
\cline { 2 - 7 } & DA & N & A & & & & \\
\hline $\begin{array}{c}\text { The travel } \\
\text { agency uses } \\
\text { modern and } \\
\text { attractive ways } \\
\text { to show and } \\
\text { sell its optional } \\
\text { tours } \\
\text { (PowerPoint } \\
\text { presentations, } \\
\text { videos, } \\
\text { pictograms). }\end{array}$ & 1 & 2.1 & 96.8 & 2.96 & .247 & 1 & High \\
\hline $\begin{array}{c}\text { The travel } \\
\text { agency }\end{array}$ & 0 & 13.4 & 86.6 & 2.87 & .342 & 4 & High \\
\hline
\end{tabular}




\begin{tabular}{|c|c|c|c|c|c|c|c|}
\hline \multirow{2}{*}{ Statement } & \multicolumn{3}{|c|}{ Percentage } & \multirow{2}{*}{ Mean } & \multirow{2}{*}{$\begin{array}{c}\text { Std. } \\
\text { Deviation }\end{array}$} & \multirow{2}{*}{ Rank } & \multirow{2}{*}{ Attitude } \\
\hline & DA & $\mathbf{N}$ & $\mathbf{A}$ & & & & \\
\hline $\begin{array}{l}\text { provides } \\
\text { optional tours } \\
\text { that suitable } \\
\text { the nature of } \\
\text { the destination } \\
\text { and your } \\
\text { desires }\end{array}$ & & & & & & & \\
\hline $\begin{array}{l}\text { The travel } \\
\text { agency } \\
\text { implements the } \\
\text { optional tours } \\
\text { as had been } \\
\text { announced and } \\
\text { purchased }\end{array}$ & 3.1 & 8.2 & 88.7 & 2.86 & .433 & 7 & High \\
\hline $\begin{array}{l}\text { The travel } \\
\text { agency } \\
\text { provides you } \\
\text { with the } \\
\text { information } \\
\text { need about the } \\
\text { trip and the } \\
\text { staff responds } \\
\text { to all your } \\
\text { inquiries. }\end{array}$ & 1 & 9.3 & 89.7 & 2.89 & .350 & 3 & High \\
\hline $\begin{array}{l}\text { You feel safe } \\
\text { during } \\
\text { implementing } \\
\text { the optional } \\
\text { tours. }\end{array}$ & 0 & 13.4 & 86.6 & 2.87 & .342 & 5 & High \\
\hline $\begin{array}{l}\text { The tour leader } \\
\text { does his fullest } \\
\text { role, caring of } \\
\text { your } \\
\text { satisfaction and } \\
\text { safety. }\end{array}$ & 2 & 5.2 & 92.8 & 2.91 & .356 & 2 & High \\
\hline
\end{tabular}




\begin{tabular}{|c|c|c|c|c|c|c|c|}
\hline \multirow{2}{*}{ Statement } & \multicolumn{3}{|c|}{ Percentage } & \multirow{2}{*}{ Mean } & \multirow{2}{*}{$\begin{array}{c}\text { Std. } \\
\text { Deviation }\end{array}$} & \multirow{2}{*}{ Rank } & \multirow{2}{*}{ Attitude } \\
\hline & DA & $\mathbf{N}$ & $\mathbf{A}$ & & & & \\
\hline $\begin{array}{l}\text { The transfers to } \\
\text { and from the } \\
\text { optional tour's } \\
\text { areas was } \\
\text { accurate and } \\
\text { smooth. }\end{array}$ & 2.1 & 10.3 & 87.6 & 2.86 & .408 & 6 & High \\
\hline
\end{tabular}

Optional Tours are considered as a type of tourism experience, thus it is defined as "a type of tourism experience where a tour operator offers travelers an opportunity to participate tourism activities, as well as a cultural exchange with local people" (Brown, 2005, p. 480). Guo et al. (2014) mentioned that the importance of Optional Tours for tour operators is to provide additional revenue. As for tourists, the Optional Tours is offering opportunities for tourists to choose activities that they want and adding flexibility to classic packaged tours. Table (11) stats that the result of Optional Tours Evaluation of foreign Tourists Sample agreed with the result of Egyptian Respondents and study of khalaf (2017), where The item "The travel agency uses modern and attractive ways to show and sell its optional tours (PowerPoint presentations, videos, pictograms)" ranked first with a mean and standard deviation (Mean=2.96, standard deviation $=.247$ ) compared with the total instrument mean and the standard deviation. The means ranged between (2.96- 2.86) compared with the total instrument mean for the domain (2.89). Large percentage $(88 \%)$ of the respondents declared that declared that the travel agency implements the optional tours as had been announced and purchased (2.86) and the standard deviation was (.433) compared with the mean and standard deviation of the total instrument. Optional excursion is now one of the main products in Egypt and has become a niche market to the country. There are several types of optional excursions in Red Sea coast (e.g. diving, snorkeling safari tours, beach buggy, etc). Destinations need now to focus on other types of tourism products which are in line with tourists' demographic characteristics and their behavior known as "Optional Tours". Optional is defined as "an adjective which means possible to add if the customer wants" (Dictionary of Leisure, Travel and Tourism, 2006, p.214). 


\subsubsection{The Fourth Part: The Overall Satisfaction Level of Foreign Tourists towards Their Trip in Marsa Alam}

Table 12: The Overall Satisfaction Level of the Foreign Sample

\begin{tabular}{|c|c|c|c|c|c|}
\hline \multirow{2}{*}{ Service } & \multicolumn{3}{|c|}{ Percentage } & \multirow{2}{*}{ Mean } & \multirow{2}{*}{ Std. Deviation } \\
\cline { 2 - 4 } & DS & N & S & & \\
\hline Optional Tours & 0 & 8.2 & 91.8 & 2.92 & .277 \\
\hline
\end{tabular}

Ninety percent of the respondents stated that they are satisfied by the level of optional tours quality (Mean=2.92, standard deviation $=.277$ ) table (12).

\subsubsection{The Fifth Part: Pearson Correlation between foreign Tourists satisfaction and optional tours services provided to them during their trip}

Table (13) Correlation between foreign tourist's satisfaction and optional tours quality

\begin{tabular}{|c|c|c|c|}
\hline & & Satisfaction & $\begin{array}{c}\text { Optional } \\
\text { Tours }\end{array}$ \\
\hline \multirow{3}{*}{ Satisfaction } & $\begin{array}{c}\text { Pearson } \\
\text { Correlation }\end{array}$ & 1 & $.632^{* *}$ \\
\hline & Sig. (2-Tailed) & & .000 \\
\hline & $\mathrm{N}$ & 97 & 97 \\
\hline \multirow{3}{*}{$\begin{array}{l}\text { Optional } \\
\text { Tours }\end{array}$} & $\begin{array}{c}\text { Pearson } \\
\text { Correlation }\end{array}$ & $.632^{* * *}$ & 1 \\
\hline & Sig. (2-Tailed) & .000 & \\
\hline & $\mathrm{N}$ & 97 & 97 \\
\hline
\end{tabular}

As seen in the table (13), there was a positive and significant relationship between security control and image perception. The value of spearman correlation coefficient was $\left(.632^{* *}-\operatorname{sig}=0.000\right)$. These results showed that there is strong positive relation between foreign tourist's satisfaction and optional tours quality. This positive correlation indicates that as foreign tourist's satisfaction increases with interest optional tours quality.

\section{Conclusion}

After discussing the findings of the research, the conclusion was extracted. The research pointed to a number of conclusions with respect to evaluate the optional tours services quality in Marsa Alam city. This conclusion can be presented in the following: 
The Optional Tours for Egyptian travel agencies are important because it provided additional revenue. As for tourists, the Optional Tour offer opportunities to choose activities that they want and add flexibility to the classic packaged tours. Tourists could purchase it during their trip, thus it increased the income of the travel agencies.

The most essential features of optional tours were trips to closer destinations in a relatively short period of time. Usually the trips did not last longer than 24 hours, which meant that, unlike other forms of travel packages, they did not include services of overnight stays. From the aspect of the duration, trips could take half a day, full day or only a few hours. Depending on the group size and characteristics of the destination itself, a specific mode of transportation was adjusted to the realization of the trip. Optional Tours could be purely recreational or purely cultural or mixed between activities.

Business operations related to the organization of the optional tours consisted of determining the excursion destination and itinerary, determining the trip content, contracting planned services, pricing, publishing the trip program, organizing sales and the realization of a concrete trip. The program of a tour consisted of transportation services, a guide, sightseeing of cultural-historical, natural and other attractions and activities, catering services, etc.

Optional Tours were considered a form of innovative product which their effect was reflected on customers and companies host community. Travel agencies have to innovate and develop new products to gain competitive advantage and services to reach consumers' satisfaction. Optional Tours considered a form of innovative products which their effects are reflected on customers, companies and host community. Tour leader played an important role not only in the selection of attractions, Optional Tours or shopping but also in the achievement of customer satisfaction.

\section{References}

Abdullah, F., Suhaimi, R., Saban, G and Hamali, J. (2011)"Bank service quality (BSQ) index: an indicator of service performance", International Journal of Quality and Reliability Management, 28(5), p542-555.

Al-Ababneh, M. (2013) "Service quality and its impact on tourist satisfaction", Interdisciplinary Journal of Contemporary Research in Business, 8(3) p173-188.

Ali, F. and Zhou, Y., (2013)"An Assessment of the Perceived Service Quality: Comparison of Islamic and Conventional Banks at 
Pakistan\|", International Journal of Innovation and Business Strategy, 2, p45-58.

Amin, M., Yahya, Z., Ismayatim, W.F.A., Nasharuddin, S.Z., and Kassim, E. (2013)"Service Quality Dimension and Customer Satisfaction: An Empirical Study in the Malaysian Hotel Industry", Services Marketing Quarterly,34(2), p115-125.

Angelova, B and Zekiri, J. (2011)" Measuring Customer Satisfaction with Service Quality Using American Customer Satisfaction Model (ACSI Model)", International Journal of Academic Research in Business and Social Sciences, 1(3), p232-258.

Ary, D, Jacobs, L and Razavieh, A. (2002)"Introduction to Research in Education", Belmont, CA: Wadsworth/Thomson, p367.

Asadpoor, S., and Abolfazli, A. (2017)"Effect of Electronic Service Quality on Customer Satisfaction and Loyalty Saderat Bank's Customers", International Journal of Scientific Study, 5(4), p407411.

Ashraf, S., Ilyas, R., Imtiaz, M., and Ahmad, S. (2018)"Impact of Service Quality, Corporate Image and Perceived Value on Brand Loyalty with Presence and Absence of Customer Satisfaction: A Study of four Service Sectors of Pakistan", International Journal of Academic Research in Business and Social Sciences, 8(2), p452-474.

Baker, D and Crompton, J. (2000)"Quality, Satisfaction and Behavioral Intentions", Annals of Tourism Research, 27(3), p785-804.

Berezina, K., Cobanoglu, C., Miller, B and Kwansa, F. (2012)"The impact of information security breach on hotel guest perception of service quality, satisfaction, revisit intentions and word-ofmouth", International Journal of Contemporary Hospitality Management, 24(7), p991-1010.

Bigné, J and Andreu, L. (2004)"Cognitive-Affective Model of Satisfaction in Leisure and Tourism Services ", Journal of Economics and Business, 21, p89-120.

Bitner, M. (1990)"Evaluating service encounters: The effects of physical surroundings and employee responses", Journal of Marketing, 54, p69-82.

Boetsch, T., Bieger, T., Wittmer, A. (2011)"A customer-value framework for analyzing airline services", Transportation Journal, 50(3), 251-270.

Bowen, D. (2001)"Antecedents of consumer satisfaction and dissatisfaction (CS/D) on long-haul inclusive tours: a reality checks 
on theoretical considerations", Tourism Management, 22(1), p49-61.

Bowen, D. and Clarke, J. (2002)"Reflections of tourist satisfaction: past, present and future", Journal of Vacation Marketing, 8(4), p297-308.

Brown, S. (2005)"Travelling with a Purpose: Understanding the Motives and Benefits of Volunteer Vacationers", Current Issues in Tourism, 8(6), p479-496.

Burns, R, Graefe, A and Absher, J. (2003)"Alternate measurement approaches to recreational customer satisfaction: Satisfactiononly versus gaps scores", Leisure Sciences, 25(4), p363-380.

Caruana, A. (2000)"Service loyalty: The effects of service quality and mediating role of customer satisfaction", European Journal of Marketing, 36(7/8), p811-828.

Chakravarty, S., Widdows, R. and Feinberg, R. (1996)"how moments of truth define bank-customer relationships", Journal of Retail Banking Services, 18(1), p29-34.

Chan, A, Hsu, C. and Baum, T. (2015)"The Impact of Tour Service Performance on Tourist Satisfaction and Behavioral Intentions: A Study of Chinese Tourists in Hong Kong", Journal of Travel and Tourism Marketing, 32, p18-33.

Chang, J. (2008)"Taiwanese Tourists ${ }^{\text {ee }}$ perceptions of Service Quality on Outbound Guided Package Tours: A Qualitative Examination of the SERVQUAL Dimensions", Journal of Vacation Marketing, Volume 15(2), p164- 178.

Chen, R., Hsiao, J and Hwang, H. (2012)"Measuring customer satisfaction of internet banking in Taiwan: scale development and validation", Total Quality Management and Business Excellence, 23(7), p749-767.

Cronin, J and Taylor, S. (1992) "Measuring service quality: a reexamination and extension", Journal of Marketing, 56(3), p5568.

Cronin, J, Brady, M and Hult, G. (2000) "Assessing the effects of quality, value, and customer satisfaction on consumer behavioral intentions in service environments', Journal of Retailing, 76(2), p193-218.

Dictionary of Leisure, (2006)"Travel and Tourism "Third Edition, London: A and C Black Publishers Ltd, p214.

Döckel, A. (2003)"The Effect of Retention Factors on Organizational Commitment: An Investigation of High Technology Employees", Master Thesis, Faculty of Economics and Management Sciences, University of Pretoria, p95-96. 
Egyptian Tourism Authority, (2020), " Hurghada, Marsa Alam, Sharm El-Sheikh and Dahab", Available at http://www.southsinai.gov.eg/tourism/atrareas/default.aspx,Accessed on: 17 Nov. 2020.

Eraqi, M. (2006)" Tourism services quality (TourServQual) in Egypt the viewpoints of external and internal customers", Emerald, 13(4), p469-492.

Farooq, M, Jaafar, N., Ayupp, K., Salam, M., Mughal, Y., Azam, F and Sajid, A. (2016)"Impact of entrepreneurial skills and family occupation on entrepreneurial intentions", Sci. Int.-Lahore 28(3), p3145-3148.

Ghotbabadi, A., Feiz, S., and Baharun, R. (2016)"The Relationship of Customer Perceived Risk and Customer Satisfaction", Mediterranean Journal of Social Sciences, 7(1), p161-173.

Glatzer, W. (2000)"Happiness: classic theory in the light of current research", Journal of Happiness Studies, 1(4), p501-511.

Guo, Q, Shi, Y, Dong, J, Guo, X and Anderson, C. (2014)"Pricing competition and channel coordination in the tourism supply chain with Optional Tours", Tourism Economics, 20(5), p939960.

Gursoy, D., McCleary, K and Lepsito, L. (2007)"Propensity to complain: effects of personality and behavioral factors", Journal of Hospitality and Tourism Research, 31 (3), p358-386.

Hu, H., Kandampully, J., and Juwaheer, D. (2009)"Relationships and impacts of service quality, perceived value, customer satisfaction, and image: an empirical study", Service Industries Journal, 29(2), p111-125.

Huang, L. (2008)"Strategic orientation and performance measurement model in Taiwan's Travel Agencies", The Service Industries Journal, 28(10), p1357-1383.

Huhtiniemi, J. (2008)"Customer Satisfaction of Internal Business Travel Services at Finnair Plc", Bachelor's Dissertation, University of Applied Sciences, p24-26.

Hui, T. and Wan, D. (2005)"Factors affecting consumers' choice of a travel agency: the case of Singapore", Journal of Travel and Tourism Marketing, 19 (4), p2-12.

Izogo, E and Ogba, I. (2015)"Service quality, customer satisfaction and loyalty in automobile repair services sector", International Journal of Quality and Reliability Management, 32(3), p250269. 
Jennings, G., and Weiler, B. (2006)"Mediating meaning: perspectives on brokering quality tourist experiences", Elsevier ButterworthHeinemann, p57-78

Jennings, G., Young L., and Ayling, A. (2009)"Quality tourism experiences: reviews, reflections, research agendas", Journal of Hospitality Marketing and Management, 18(2), p294-310.

Karatepe, O., Yavas, U. and Babakus, E. (2005) "Measuring service quality of banks: Scale development and validation", Journal of Retailing and Consumer Services, 12(5), p373- 383.

khalaf, M. (2017)" Developing the Tour Leader Performance in Egypt", Unpublished Master's thesis, Faculty of Tourism and Hotels, Minia University, p65-70.

Kotler, P and Caslione, J. (2009)"How marketers can respond to recession and turbulence", Journal of Customer Behavior, 8(2), p187-191.

Lawson, S., Manning, R., Valliere, W., and Wang, B. (2003)"Proactive monitoring and adaptive management of social carrying capacity in Arches National Park: An application of computer simulation modelling", Journal of Environmental Management, 68(3), p305-313.

Lennon, R., and Harris, J. (2002)"Customer service on the web: A cross-industry investigation", Journal of Targeting Measurement and Analysis for Marketing, 10(4), p325-328.

MacCannell, D. (2002)"The Ego Factor in Tourism", Journal of Consumer Research, 29(1), p146-151.

Mancini, M (2012)"Conducting tours: A practical guide", Cengage Learning, Inc., USA, Available at: https://books.google.com, accessed on: Nov, 2020.

Meng, F., Li, X. and Uyasl, M. (2010)"Tourism Development and Regional Quality of Life: The Case of China", Journal of China Tourism Research, 6(2), p164-182.

Namukasa, J. (2013)"The influence of airline service quality on passenger satisfaction and loyalty The case of Uganda airline industry", The TQM Journal, 25(5), p520-532.

Oliver, R. (1981)"Measurement and evaluation of satisfaction processes in retail settings", Journal of Retailing, 57(3), p25-48.

Onome, D. (2003)"Destination environment quality and tourists' spatial behavior in Nigeria: A case study of third world tropical Africa", The International Journal of Tourism Research, 5(4), p251-268. 
O'Sullivan, D and McCallig, J. (2012) "Customer satisfaction, earnings and firm value", European Journal of Marketing, 46 (6), p827-843.

Paul, V. and Sreejesh, S. (2017)"Impact of responsible tourism on destination sustainability and quality of life of community in tourism destinations", Journal of Hospitality and Tourism Management, 31, p83-89.

Prabaharan, B.; Arulraj, A. and Rajagopal, V. (2008)"Service quality on tourism: application of structural equation modeling", Conference on tourism in India-Challenges Ahead, p143-150.

Radovic-Markovic, M., Farooq, $\mathrm{M}$ and Markovic, D. (2017)"Strengthening the resilience of small and medium-sized enterprises", Presented at the Management, Enterprise and Benchmarking in the 21st Century, Óbuda University, Budapest, p345-356.

Ranaweera, C., and Prabhu, J. (2003)"The influence of satisfaction, trust and switching barriers on customer retention in a continuous purchasing setting", International Journal of Service Industry Management, 14(4), p374-395.

Red Sea Governorate, (2020), "The Red Sea Governorate", Available at http://www.redsea.gov.eg/tourism/default.aspx, Accessed on: 17 Nov. 2020

Richey, R, Tokman, M and Dalela, V. (2010)"Examining collaborative supply chain service technologies: a study of intensity, relationships and resources", Journal of the Academy of Marketing Science, 38 (1), p71-89.

Roy, D, Mokta, M and Kamrul, M. (2016)"Factors Affecting Tourist Satisfaction: A Study in Sylhet Region", ABC Research Alert, 4(3), p9-20.

Sadeh, E, Asgari, F, Mousavi, L and Sadeh, S. (2012)"Factors Affecting Tourist Satisfaction and Its Consequences", Journal of Basic and Applied Scientific Research, 2(2), p1557-1560.

Seth, N., Deshmukh, S and Vrat, P. (2005)"Service quality models: a review", International Journal of Quality and Reliability Management, 22(9), p913-949.

Singh, R. and Tomar, D. (2013)"Measuring Foreign Traveler's Satisfaction with Traveling Agencies in India", IOSR Journal of Business and Management, 12(1), p26-32.

Sirakaya, e, Petrick, J and Choi, H. (2004)"The role of mood on tourism product evaluations", Annals of Tourism Research, 31(3), 517-539. 
Sofronov, B. (2019)"The Development of Marketing in Tourism Industry", Annals of Spiru Haret University Economic Series 1(1), p117-127.

Stetic, S, Simicevic, D and Sara, S. (2011)"Same-Day Trips: A Chance of Urban Destination Development", UTMS Journal of Economics 2 (2), p113-124.

$\mathrm{Su}, \mathrm{M}$. and Wall, G. (2010)"Implications of host-guest interactions for tourists' travel behavior and experiences", TOURISM, 58(1), p37-50.

Sukri, S., Abdullah, F., and Waemustafa, W. (2014)"Customer satisfaction and loyalty in the airline industry: a case study of Malaysia airlines (mas) and air Asia", International Case Study Conference, Putra World Trade Centre, Malaysia, p43-69.

Tabaku, E. and Kushi, E. (2013)"Service quality, customer satisfaction, perceived value and brand loyalty: a critical review of the literature", Academic Journal of Interdisciplinary Studies, 2(9), p223-228.

Tse, D and Wilton, P. (1988)"Models of consumer satisfaction formation: An extension", Journal of Marketing Research, 25(2), 204-212.

Vajčnerova, I and Ryglova, K. (2014) "Key Factors of Quality in the Sector of Tourism Services Providers: Case Study: Czech Republic", Acta Universitatis Agriculturae et Silviculturae Mendelianae Brunensis, 62(6), p1493-1497.

Wang, K, Hsieh, A. and Chen, W. (2002)"Is the Tour Leader an effective endorser for group package tour brochures?", Tourism Management, 23 (5), p489-498.

Warden, C., Liu, T., Huang C., and Lee, C. (2003)"Service failures away from home: Benefits in intercultural service encounters", International Journal of Service Industry Management, 14(3/4), p436-456.

Weng, J and de Run, E. (2013)"Consumer's 'personal values and sales promotion preferences effect on behavioral intention and purchase satisfaction for consumer product", Asia Pacific Journal of Marketing and Logistics, 25(1), p70-101.

Westbrook, R and Oliver R. (1991)"The dimensionality of consumption emotion patterns and consumer satisfaction", Journal of Consumer Research 18(1), p84-91.

Yoon, Y and Uysal, M. (2005)"An examination of the effects of motivation and satisfaction on destination loyalty: A structural model", Tourism Management, 26(1), 45-56. 
Yu, p. (2012)"Chinese Outbound Travel and the Ling-Tuan-Fei Phenomenon: The New Zealand Case the Ling-Tuan-Fei Tour to New Zealand: Poison, panacea or palliative?", Master Dissertation, Auckland University of Technology, p93.

Yuksel A, Yuksel F. (2002)"Measurement of tourist satisfaction with restaurant services: A segment-based approach", Journal of Vacation Marketing 9(1), p52-68. 